\title{
Making sense of smart cities: addressing present shortcomings
}

\author{
Rob Kitchin
}

National Institute for Regional and Spatial Analysis, National University of Ireland
Maynooth, County Kildare, Ireland, Rob.Kitchin@nuim.ie

Received on July 15, 2014; accepted on August 7, 2014

This commentary characterises and critiques research on smart cities. I argue that much of the writing and rhetoric about smart cities seeks to appear non-ideological, commonsensical and pragmatic. More critically orientated scholarship, while making vital conceptual and political interventions, presently has four shortcomings that inhibit making sense of and refashioning the smart city agenda: the lack of detailed genealogies of the concept and initiatives, the use of canonical examples and one-size fits all narratives, an absence of indepth empirical case studies of specific smart city initiatives and comparative research that contrasts smart city developments in different locales and weak collaborative engagement with various stakeholders. These shortcomings are elaborated, accompanied with suggestions for addressing them.

Keywords: smart cities, theory, empirical research, critical scholarship

JEL Classifications: R00, R58

Over the past 15 years, the concept of smart cities has gained traction amongst businesses, governments, the media and academia to refer to, on the one hand, the use of information and communication technologies (ICTs) to stimulate economic development and, on the other, the extensive embedding of softwareenabled technologies into the fabric of cities to augment urban management (Kitchin, 2014). With respect to the first vision, a smart city is one whose economy is increasingly driven by technically inspired innovation, creativity and entrepreneurship, enacted by smart people (Kourtit et al., 2012). It is posited that smart policies and judicious investment in appropriate fiscal measures, human capital and technological infrastructures and programmes will attract businesses and jobs, create efficiencies and savings and raise the productivity and competitiveness of government and businesses (Caragliu et al., 2009). The second perspective envisages a smart city as one that can be monitored, managed and regulated in real-time using ICT infrastructure and ubiquitous computing (Townsend, 2013). These real-time systems enable the efficient control of urban utilities and services, the enforcement of public safety and security and an effective response to economic 
and environmental shocks. The data generated can also be used to better depict, model and predict urban processes and simulate future urban development (Batty et al., 2012). Cities can, of course, pursue becoming smart in both economic and regulatory terms.

Just as there are differences in the conception of a smart city, the academic, business and government literature is largely divided with respect to the ideological rhetoric and theoretical orientation underpinning their vision. Many academics working on developing smart city technologies and policy formulations-especially those in the sciences and computational social sciences-position their work as pragmatic and non-ideological. They are producing technologies and ideas that will create economic growth or improve governance. Similarly, businesses seek to present their initiatives as being city- and citizen-orientated; their vision is commonsensical and inclusive. This despite the fact that they are vested interests pushing for the adoption of market-led and technological solutions to city administration, while at the same time seeking deregulation, privatisation and more open economies that weakens oversight and enable more efficient capital accumulation. Likewise, municipal and national governments, along with supra-national states, such as the European Union, positively endorse the smart city concept as the path to socio-economic progress and more liveable, secure, functional, competitive and sustainable cities.

Smart city advocates imagine themselves as creating technologies, techniques and visions that are scientific, objective, commonsensical and apolitical. In general, there is little critical reflection on the wider implications of technologically rooted entrepreneurial urban development, or the consequences of networked urbanism, for city administrations and citizens. Left untouched are issues such as panoptic surveillance, technocratic and corporate forms of governance, technological lock-ins, profiling and social sorting, anticipatory governance, control creep, the hollowing out of state provided services, widening inequalities and dispossession of land and livelihoods (especially on green field sites) (Datta, in press; Greenfield, 2013; Townsend, 2013; Kitchin, 2014). Such issues have serious consequence with respect to the form and nature of city administration and citizen freedoms and reveal the concept of a smart city to be far from apolitical and non-ideological.

This largely hegemonic discourse is countered by a relatively small cadre of more critically oriented urban scholars who have sought to unpack, contextualise and make theoretical sense of smart city rhetoric and initiatives. In general, their work has focused on the neoliberal ethos underpinning the smart city concept (Hollands, 2008; Greenfield, 2013; Vanolo, 2014) or on developing a more inclusive notion of a smart city (Hill, 2013; Townsend, 2013). This critical scholarship, vital in countering the supposedly pragmatic, non-ideological, commonsensical visions of the smart city, presently has four shortcomings that inhibit making sense of and refashioning the smart city agenda: the lack of detailed genealogies of the concept and initiatives, the use of canonical examples and one-size fits all narratives, an absence of indepth empirical case studies of specific smart city initiatives and comparative research that contrasts smart city developments in different locales and weak collaborative engagement with various stakeholders.

Uncovering the antecedents of the smart city, and the unfolding of specific smart city initiatives, will illuminate the ways in which the concept is bound up in the shifting rhetoric and socio-spatial processes of governance and economic development. However, to date, there has been little genealogical excavation of the smart city concept and how it has been formulated and deployed over time, space and by stakeholders beyond a handful of quite thin origin stories. These accounts contend that the smart city has its initial roots in the high modernist urban planning of the mid-20th century (Greenfield, 2013) and the urban cybernetics 
of the 1970s (Townsend, 2013) but is more firmly anchored to two moorings: first, to the neoliberal re-visioning of city managerialism, the development of urban entrepreneurship in the 1980s and 90s and the concepts of smart growth and new urbanism (Hollands, 2008; Wolfram, 2012; Söderström et al., 2014; Vanolo, 2014). The smart city is understood to be the technological version of a sequence of neoliberal-infused new urban visions, including competitive cities, creative cities, sustainable cities, resilient cities and green cities. Second, to initial conceptualisations of the relationship between ICT and cities and the development of networked urbanism (Graham and Marvin, 2001), including 'wired cities' (Dutton et al., 1987), 'cyber cities' (Graham and Marvin, 1999), 'digital cities' (Ishida and Isbister, 2000) and 'intelligent cities' (Komninos, 2002). These ICT-infused city visions have largely been corralled within the concept of the smart city, in part due to the popularisation of the term within public discourse. ${ }^{1}$ Nonetheless, our understanding of the wider channels and drivers of the concept is sketchy.

Moreover, there is a need to carefully trace out how the concept continues to find new avenues and ideas to finesse and extend its development and evolves and morphs in the face of critique and push back. It is noticeable, for example, how smart city vendors such as IBM and Cisco have started to alter the discursive emphasis of some of their initiatives from being top-down managerially focused to stressing inclusivity and citizen empowerment. Through such discursive moves, advocates seek to silence or turn detractors and bring them into the fold while keeping their central mission of capital accumulation and technocratic governance intact.

These genealogies need to be accompanied by critical accounts that are more nuanced and differentiated in their analysis. The logic, drivers and deployment of smart city initiatives in different places is often quite varied. There is still a tendency to package smart city discourses and effects into a one-size fits all narrative and to use a handful of canonical examples as indicative of all initiatives and cities. Cities undoubtedly share similar forms and systems, but they also have diverse histories, cultures and political economies and variegated forms of capitalism that shape patterns of urban and economic development and the relationship between state, market and society. Visions of smart cities, how they dovetail with local and global political economies, and how they unfold in practice, vary between places. Smart city developments in India and China, for example, while often using similar rhetoric and the same technologies, are often unfolding in quite different ways to Philadelphia or Dublin (Datta, in press; Wiig, forthcoming). And there are marked differences between retrofitting existing cities and building brand new cities on green field sites.

At present, canonical examples of smart city developments, appearing in nearly every academic paper or media report, are Songdo (South Korea), Masdar (United Arab Emirates), PlanIT Valley (Portugal) and Rio de Janeiro (Brazil). The first three are large, green field developments wherein an entire smart cityfestooned with digital infrastructures and the internet of things - are being built from scratch through public-private partnerships. The latter focuses on the integrated, big data-fed control room put in place by IBM for the city's hosting of the World Cup 2014 and Olympic Games 2016 (see Kitchin, 2014). Somewhat paradoxically, developments that are quite exceptional in nature, rather than typical (existing cities seeking to retrofit infrastructures and systems), have become master tropes for smart cities. As key sites of testbed urbanism (Halpern et al., 2014), they provide idealised visions of possible futures, while avoiding the messy realities of established cities. Similarly, it is clear from talking to different stakeholders that they hold different visions and ambitions-companies such as IBM, Cisco, Siemens, Intel and SAP do not fully share a conception of smart cities, in part due to different corporate ethos, but also because they are competing oligopolists selling 


\section{Kitchin}

different products (for example, consultancy, networks, hardware and devices, chips, software, system solutions). Moreover, governments and political parties have alternative priorities. The nature of these differences and how they are negotiated together into the complex assemblage of a smart city needs to be teased apart.

One of the principal reasons why one-size fits all narratives and canonical examples dominate present academic accounts is the lack of indepth empirical case studies of a range of smart city developments and comparative research of similar initiatives in different locales. While quite a few papers document attempts to create smart city technologies from a technical perspective, and others provide synoptic overviews and critique of the smart city concept, there are relatively few detailed case studies of specific cities, programmes or stakeholders based on extensive fieldwork. Critique seems to largely be based on the reading of corporate or government documents, rather than interviews, ethnographies or genealogies that would add substantive insight into:

- how the discursive terrain of a smart city is fashioned in local and regional context;

- how the rhetoric deployed dovetails with or diverges from other economic and governance initiatives designed to refashion the city;

- how specific initiatives are formulated and draw on and adapt arguments from elsewhere;

- how initiatives gain political and financial backing, negotiate local and national policy debates and unfold over time;

- the ways in which initiatives are rolled out in practice and are fractured and reworked in the messy realities and politics of implementation and contestation;

- how different initiatives, led by a plethora of stakeholders, work together or compete to produce a certain kind of smart city;

- what the effects of different techno-social arrangements are on urban systems, economic sectors and populations;
- the extent to which initiatives create or perpetuate inequalities between communities;

- how initiatives are evaluated and their costs and benefits communicated to the public.

Such insights would reveal the discursive and material realities of actually existing smart city developments. These could be illuminated further through a series of comparative studies that contrast the experiences of different cities - both cities in which we might expect similarities in initiatives and effects (for example, cities of roughly the same size in the same jurisdiction) and those which we might expect to differ but are presently discussed as if they are similar (for example, cities in the Global South and North, green field and retrofitting developments). The former would enable the particularities of smart city initiatives and their effects on economic development and regimes of governance to be teased apart. The latter would reveal the ways in which smart city rhetoric and implementation are being produced and grounded in quite different contexts and the ways in which the concept travels and mutates.

Finally, in my experience, critical scholars are reluctant to work formally with more technically orientated academics or business and government stakeholders. The former might study the latter, and the latter might react to the critique of the former. Hardly ever, however, do critical scholars undertake applied research aimed at creating smart city initiatives, preferring to critique instead. ${ }^{2}$ Likewise, technical scholars and stakeholders rarely engage with critical social theory to think through the wider implications of their work. Yet both could learn from such endeavours. Breaking down this barrier is an approach that we have sought to adopt in a 5 year, European Research Council funded project, The Programmable City. ${ }^{3}$ As well as critically examining smart city initiatives, we are creating the Dublin Dashboard, a real-time, interactive mapping and graphing website, working in collaboration with Dublin City Council. 
We are also discussing potential projects with companies such as Intel and Microsoft. And we are collaborating with more technically orientated academics in the formation of a new smart cities research centre that will include critical scholars and computer scientists. The aim is to learn and critically reflect by doing, at the same time as engaging in critical discussion about the politics of the initiatives aimed at reshaping their unfolding (for example, ensuring in the case of the Dublin Dashboard that all the data and tools available to the municipality are also available to citizens). Our initial impression is that much more insight is gained through the productive exchange of ideas and views, along with better access to key informants, than simply staring in and critiquing from the outside. Clearly, the approach has dangers in terms of 'going native' but is countered by our commitments to critical scholarship, emancipatory politics and on-going self-reflexivity. And, interestingly, we have mostly found stakeholders to be receptive to critical debate and dialogue rather than being defensive and standoffish, in part because both government and companies increasingly employ social scientists trained to doctoral level. ${ }^{4}$

This short commentary has made the case that smart city research is at a relative early stage with respect to its conceptual development and empirical understanding. While the term has gained popular traction amongst academics, businesses, government and media, accounts tend to either be idealistic and/or technical, or critical but lacking in nuance and/or empirical evidence. Given how quickly the smart city concept has gained traction and been translated into forms of networked urbanism, reshaping city administration and urban economic development and the rapid unfolding of initiatives involving hundreds of billion dollars worth of city revenue and private equity, it is vital in my view that the four shortcomings I have discussed are addressed.

\section{Endnotes}

${ }^{1}$ The popularisation of the term has been driven to a large degree by IBM's high profile 'smarter cities challenge' (Söderström et al., 2014). Launched in 2010, the challenge invited cities from around the world to compete for consultancy, technical assistance and grants aimed at developing technological solutions to nine grand city challenges (administration, citizen engagement, economic development, education and workforce, environment, public safety, social services, transportation, urban planning; IBM 2013).

2 Though leading critical commentators Adam Greenfield, Anthony Townsend and Dan Hill have all undertaken work to create forms of networked urbanism and have worked on urban consultancy projects.

${ }^{3}$ http://www.nuim.ie/progcity/

${ }^{4}$ For example, Kate Crawford and Genevieve Bell, two of the most cited and respected critical commentators on big data and software studies, are employed by Microsoft and Intel, and the principal investigator of Intel's Sustainable Connected Cities programme, David Prendergast, is a former academic anthropologist.

\section{Acknowledgements}

I would like to thank Amy Glasmeier and Jim White for useful feedback and editorial advice on the drafting of this commentary. This paper was supported by a European Research Council Advanced Investigator Award, 'The Programmable City' (ERC-2012-AdG-323636).

\section{References}

Batty, M., Axhausen, K. W., Giannotti, F., Pozdnoukhov, A., Bazzani, A., Wachowicz, M., Ouzounis, G., Portugali, Y. (2012) Smart cities of the future, European Physical Journal Special Topics, 214: 481-518.

Caragliu, A., Del Bo, C., Nijkamp, P. (2009) Smart Cities in Europe. Series Research Memoranda 0048. VU University Amsterdam, Amsterdam, Faculty of Economics, Business Administration and Econometrics.

Datta, A. (in press) New urban utopias of postcolonial India: 'Entrepreneurial urbanization' in Dholera smart city, Gujarat, Dialogues in Human Geography. 
Dutton, W. H., Blumler, J. G., Kraemer, K. L. (1987) Wired Cities: Shaping Future Communication. New York: Macmillan.

Graham, S. and Marvin, S. (1999) Planning cybercities: integrating telecommunications into urban planning, Town Planning Review, 70: 89-114.

Graham, S. and Marvin, S. (2001) Splintering Urbanism: Networked Infrastructures, Technological Mobilities and the Urban Condition. New York: Routledge.

Greenfield, A. (2013) Against the Smart City. New York: Do Publications.

Halpern, O.,LeCavalier,J., Calvillo, N.,Pietsch,W.(2014) Test-bed urbanism, Public Culture, 25: 273-306.

Hill, D. (2013) On the smart city: or, a 'manifesto' for smart citizens instead. City of Sound, 1 February 2013. Available online at: http://www.cityofsound. $\mathrm{com} / \mathrm{blog} / 2013 / 02 /$ on-the-smart-city-a-callfor-smartcitizens-instead.html [Accessed 5 February 2013].

Hollands, R.G. (2008) Will the real smart city please stand up? City, 12: 303-320.

IBM. (2013) IBM Smarter Cities Challenge: Challenges and Cities. Available online at: http:// smartercitieschallenge.org/smarter-cities.html [Accessed 14 July 2014].

Ishida, T. and Isbister, K. (2000) Digital Cities: Technologies, Experiences, and Future Perspectives. LNCS 1765. Berlin: Springer.
Kitchin, R. (2014) The real-time city? Big data and smart urbanism. GeoJournal, 79: 1-14.

Komninos, N. (2002) Intelligent Cities: Innovation, Knowledge Systems and Digital Spaces. London: Routledge.

Kourtit, K., Nijkamp, P.,Arribas-Bel, D. (2012). Smart cities perspective - A comparative European study by means of self-organizing maps, Innovation, 25: 229-246.

Söderström, O., Paasche, T., Klauser, F. (2014) Smart cities as corporate storytelling, City, 18: 307-320.

Townsend, A. (2013) Smart Cities: Big Data, Civic Hackers, and the Quest for a New Utopia. New York: W.W. Norton \& Co.

Vanolo, A. (2014) Smartmentality: the smart city as disciplinary strategy, Urban Studies, 51: 883-898.

Wiig, A. (forthcoming) After the Smart City: Global Ambitions and Urban Policymaking in Philadelphia [Doctoral Dissertation]. Philadelphia: Temple University.

Wolfram, M. (2012). Deconstructing smart cities: an intertextual reading of concepts and practices for integrated urban and ICT development. In M. Schrenk, V. V. Popovich, P. Zeile, P. Elisei (eds.) Re-Mixing the City: Towards Sustainability and Resilience? pp. 171-181. REAL CORP. 